\title{
Reviving the American Labor Movement: Institutions and Mobilization
}

\author{
Richard Hurd, Ruth Milkman and Lowell Turner
}

The reawakening of the American labor movement under new leadership with new strategic orientations is a remarkable chapter in late 20thcentury American economic and political history. Given up for dead by so many at home and abroad, under relentless attack from American employers and with government supports disappearing, the American Federation of Labor and Congress of Industrial Organizations (AFLCIO) and a core of key member unions have re-emerged since the mid-1990s as prominent workplace, community and political actors. With both strategic reorientation and new local mobilization, these unions have fought to reverse decline and re-energize the movement. While the new efforts have not yet yielded enduring membership or national legislative gains, American unions have repositioned themselves for a potential organizing renaissance.

While domestic in substance, this is an important international story. The long decline of the American labor movement neutralized a central locus of opposition to the rise of market fundamentalism, deregulation and unfettered free trade in a US-dominated global economy. Even the strongest unions, in northern Europe, for example, have come under growing pressure from policies of fiscal and monetary austerity. Prospects for the revival of the American labor movement are thus a matter of global significance.

\section{The Argument}

To the extent that revitalization of the American labor movement is under way, our research indicates that it is driven primarily by two forces: from above, new leadership in some unions and at the AFL-CIO, ready to offer support for local efforts to organize, build coalitions and expand grass-roots politics; from below, renewed interest in rank-and-file activism and participation. We take issue with those who argue that strong unions depend primarily on centralized authority and institutions (for example, Soskice, 2000; Wallerstein and Golden, 2000). On the other hand, we disagree with the argument often found in radical sociology and in the social movement literature, that union revitalization primarily depends on rank-and-file mobilization (Brecher and Costello, 1994; Kelly, 1998).

Both perspectives are to a significant extent accurate, but not in their mutual exclusion. Local union reform efforts, including organizing the unorganized, innovative collective bargaining campaigns, coalition building and grass-roots political action, depend for their development and sustainability on both strategic support from the national union and new rank-and-file leadership and mobilization (Voss and Sherman, 2000). These two forces can be summed up as institutional support and network mobilization, and we find indications of their overriding importance in all six of the union strategies on which our research is focused: organizing, political action, coalition building, labor-management partnership, organizational change and international solidarity. In numerous case studies, we have found a juxtaposition of conventional and more innovative strategies, with widespread tension between top-down and bottom-up approaches. With great 
regularity, however, we have found that both top-down support and bottom-up participation are necessary for sustained success in the contemporary revitalization of the American labor movement.

None of the dominant conceptual frameworks predicted the AFL-CIO's turn toward organizing and local mobilization. Both postwar industrial relations and new institutional perspectives favor system stability, taking institutions and bargaining arrangements as given. Strategic choice with its focus on transformation is more dynamic, reflecting changing world markets and power relations; yet the emphasis is still on shoring up collective bargaining and shifting toward labor-management cooperation. Our work, by contrast, seeks to integrate institutions, global markets, politics and social movements into a comprehensive actor-based framework. We are especially interested in describing and explaining contemporary labor activism, its presence or absence, successes and failures.

\section{Organizing}

The linchpin of contemporary union revitalization efforts in the USA is new organizing. The steep decline in membership over recent decades, which by the year 2000 had brought union density to a postwar low of 13.5 percent (and only 9.0 percent in the private sector), must be reversed if unions are to have any hope of regaining the influence they had in the mid-20th century. The new AFL-ClO leadership headed by John Sweeney, elected to the Federation's presidency in 1995 on a New Voice' platform, is keenly aware of this problem and has offered an array of material and moral incentives to affiliates (Sweeney, 1996). Some promising approaches have emerged in the past decade, and the number of new workers organized has increased substantially: on AFL-CIO estimates, from fewer than 100,000 workers a year before 1995 to about 350,000 in the year 2000 . Yet the number of existing union members lost through business closures or relocations and retirements has also been great: there was a net loss of about 200,000 union members in the year 2000 . Thus reversing the overall decline in union density remains elusive. Perhaps most alarming, the absolute number of union members in the USA was less at the end of 2000 than in 1992.

Increased organizing efforts, thus far, have been concentrated in relatively few unions. Reports from affiliated unions indicate that 80 percent of all new workers organized in the year 2000 were recruited by 10 of the AFL-ClO's 66 national affiliates and nearly 50 percent by only three unions. The Service Employees International Union (SEIU) claimed 70,000 new recruits, while two other unions (the United Food and Commercial Workers and the International Brotherhood of Electrical Workers (IBEW)) reported organizing 50,000 workers.

The AFL-CIO's primary message throughout the Sweeney years has been to reallocate resources. As a relatively weak center, the federation can do little more than encourage member unions to embrace organizing as a priority and offer general guidelines. Promising approaches have been developed by a number of unions, including the Hotel Employees (HERE), Communications Workers (CWA), and Needle Trades and Textile Employees (UNITE); but SEIU's innovative organizing strategies are arguably the most comprehensive. It has taken a proactive approach, identifying key sectors, industries, occupations, and local labor markets, and complementing this strategic planning process with extensive background research on the selected organizing targets. By analyzing the power structure of the target industry and 
identifying key players and critical points of vulnerability, the SEIU has been able to counter the enormous advantages employers enjoy in the current political and legal environment. Money, strategic planning and research are ways in which national union support is critical to organizing success.

With strategic planning backed up by research, the SEIU has learned how to mobilize workers, using dramatic tactics designed to maximize media coverage, often drawing on the energies of existing members through 'internal organizing'. These rank-and-file-oriented efforts are carefully orchestrated with the goal of capturing the support of the wider community. Yet the new organizing model is not simply 'bottom-up' unionism. On the contrary, a crucial ingredient in the SEIU's success has been strong leadership from the top, including a willingness to displace local union officials reluctant to embrace organizing. It is the combination of support and leadership from the national union with local rank-and-file mobilization that most often yields organizing success.

Another hallmark of the new organizing efforts pioneered by the more innovative unions is their rejection of the traditional recognition procedure administered by the National Labor Relations Board (NLRB). Unions today widely regard the NLRB election process as giving the advantage to employers, and in any event, the increasingly complex employment relationships of subcontracting and contingent employment necessitate alternative means of gaining recognition. HERE, for example, relies on demonstrations and community coalitions (including churches, human rights groups and elected local politicians) to pressure employers to recognize the union voluntarily. A similar approach is used by UNITE to build support for workers among the consumers of the targeted firm's products. The CWA has been a leading innovator in 'bargaining to organize', using its leverage in contract negotiations to secure agreements from employers to remain neutral in campaigns to organize non-union facilities and subsidiaries.

As Bronfenbrenner (1997) has documented, rank-and-file-intensive organizing strategies are typically more successful than traditional bureaucratic methods. Yet the transition to a focus on new external organizing has proved quite difficult, since local officials and staff accustomed to servicing existing memberships have proven resistant to change, as have current members accustomed to these services (Fletcher and Hurd, 2001). Precisely because of the difficulties in transforming local and national unions dominated by more traditional leaderships, the AFLCIO under Sweeney has tried to provide incentives to its affiliates to innovate and focus on organizing. With mixed success, the federation has subsidized several multi-union cooperative campaigns. Potentially more important, it has launched initiatives such as 'Union Cities', to revitalize central labor councils (local arms of the AFL-CIO) in order to foster new organizing and rebuild labor's power at the grass roots (Kriesky, 2001). Also important is the Organizing Institute, which trains young people and places them in unions around the country (Foerster, 2001).

In spite of these efforts, the reality is that the AFL-CIO is decentralized, and its leaders exert limited influence over the activities of national affiliates. The weakness of the center in this loosely structured federation is a serious obstacle to revitalization efforts: it possesses no equivalent to the trusteeship mechanism used by the SEIU and other unions to exert control over locals by replacing the entire leadership. Considering the difficulties of fostering organizational change inside the labor movement, together with the longstanding external problems of fierce employer opposition, the task of reversing the decline in union density through organizing remains a formidable one. 


\section{Political Action}

National unions have for the most part long accepted the coordinating role of the AFL- CIO in the political arena, thus it is not surprising that efforts by the Sweeney administration to centralize control of political strategy have been broadly supported. The most notable change has been a dramatic increase in funding for the AFL-CIO political operation: in 1996, in response to the anti-labor bias of the Republican-controlled Congress, affiliated unions agreed to a special assessment totalling US\$35 million to finance expanded electoral activities. Comparable funding was approved for the 1998 and 2000 election cycles (Dreyfus, 2000).

In 1996, the special political fund was earmarked for grass-roots mobilization and member education in 85 targeted congressional districts, although in the end, most of the effort was concentrated in $\mathbf{4 5}$ districts with vulnerable Republican representatives. Although the explicit objective was to create 'sustainable grassroots union organizations', in reality, well in excess of half the expenditure was on television advertising contrasting the positions of the candidates on legislation important to working people. The balance of the funds supported voter registration, phone banks and get-out-the-vote efforts. Although the objective of recapturing control of the House of Representatives was not achieved in 1996, the Republican majority was reduced and President Clinton was reelected. Labor played a key role in defeating the incumbent in 18 of the 45 target districts, a 40 percent win rate - impressive given that 95 percent of incumbents nation-wide were re-elected that year. Equally important, exit polls revealed a substantial increase in voter participation among union households, particularly in targeted districts. Overall, union households accounted for 23 percent of the voters, compared to 19 percent in 1992 . In House elections, union voters supported Democrats by two to one, compared to an 8 percent Republican advantage in households without a union member (Molyneux, 1996).

With the bulk of the money going on advertising, it is not surprising that the grass-roots political structures set up for the election dissolved and had to be rebuilt in 1998 . The larger share of funds devoted to the field effort in 1998 improved the ability to reach members directly. Shortly before the autumn elections, a referendum in California prodded labor to a successful grass-roots initiative against Proposition 226, which under the guise of 'paycheck protection' would have greatly reduced the unions' ability to engage in political activity. In Congressional elections, 70 percent of union voters supported Democrats.

The major accomplishments of labor's heightened political involvement have, nonetheless, been defensive: defeating 'paycheck protection' and 'fast-track' trade legislation, and forestalling Republican attacks on unions such as the Team Act (which would have encouraged non-union representative structures). The major positive accomplishments have been on legislation only indirectly beneficial to unions, such as increases in the minimum wage.

In an effort to boost political influence, the $1999 \mathrm{AFL}-\mathrm{ClO}$ convention took the unusual step of endorsing Al Gore for president prior to the primary season. Had Gore captured the White House, labor would have been positioned to push more aggressively a labor-friendly political agenda. In 2000, the grass-roots effort was also extended, with extensive campaigns in 71 targeted districts. The AFL-CIO placed 1000 political coordinators in these and other key districts, compared to 400 in 1998 and 200 in 1996 (Bernstein, 2000). While the grass-roots effort still relied on traditional methods ('AFL-ClO members handed out 14 million leaflets at work sites, 
mailed out 12 million pieces of campaign literature, and made 8 million phone calls' (Hoffman, $2000)$ ), this could not have been accomplished without networks of volunteers recruited by unions to participate in the campaign. In spite of Gore's defeat and the failure of the Democratic Party to gain control of Congress, the share of voters coming from union households increased again, to 26 percent. Labor is widely credited for providing Gore's victory in the popular vote, and his ability to carry key states such as Michigan, Wisconsin and Minnesota in last-minute surges attributed to heavy union turnout. The reduced Republican margin in the House and the tie in the Senate would have been unlikely without labor's leadership in the field (Hoffman, 2000).

Perhaps most encouraging for labor from a long-range perspective, in those states where the grass-roots campaign was most extensive, the results were extraordinary. The best example is Colorado: after the close defeat of the union-endorsed candidate in the 1998 governor's race, the state federation and three central labor councils (with support from the national AFL-CIO) developed a volunteer network and designed a grassroots campaign for 2000 . To shift the balance of power in the state senate, 10 districts with the highest union membership density were selected. A voter-registration drive signed up 7200 new union voters; affiliated local unions agreed to pay release time for 44 full-time and 74 part-time staff, while volunteers served as district coordinators; 1300 volunteers were recruited and trained to staff phone banks and visit the homes of union members. The end result was that although Bush carried solidly Republican Colorado by eight points, labor's campaign succeeded in seven of the target districts and the Democrats gained control of the state senate for the first time in 40 years.

However, labor still faces a difficult set of challenges in the political arena. In addition to several anti-labor executive orders, President Bush has made three anti-union administrative decisions: to open the USA to Mexican lorries against the objections of the Teamsters Union; to halt a strike by Northwest Airlines mechanics at the request of the company; and to end unilaterally the federal labor-management partnership. In the legislative arena, he supported the repeal by Congress of ergonomic regulations designed to protect workers from repetitive stress injuries, and introduced a federal version of 'paycheck protection' to reduce union political activity (this is the one initiative in this direction that has not been adopted). Reacting to this offensive, a number of unions have broken ranks and begun to work with the president and Republican congressional leaders on narrow issues that benefit only their specific members. Thus the steelworkers have secured import restrictions on steel, a consortium of unions led by the teamsters supported drilling for oil in Alaska in spite of widespread environmental concerns, and the autoworkers endorsed relaxed fuel consumption standards for motor vehicles (Durkin, 2001). While these defections have not threatened the AFLCIO's coordinating role on most legislative and electoral matters, they have damaged labor's important, but tenuous, alliance with environmental groups.

Despite such problems, there is no doubt labor has improved its overall effectiveness in the electoral arena. The political programme has increased membership participation, with a direct impact on election outcomes. Unfortunately, electoral progress has not yet translated into significant victories of the sort needed to enhance the right to organize or otherwise extend the reach of unions in the USA. Promise for the future lies in the demonstrated ability to mobilize at the grass roots in support of labor's political agenda. The need to combine top- down support with member activism is clearly evident in the experiences of unions in the political realm. While the increase in resources and staff expertise at the national level has played a significant role, the 
crucial ingredient is the political field operation and its ability to deploy members as volunteers in extensive grass-roots operations.

\section{Coalitions}

Coalition building has been another central component of the revitalization of the American labor movement. The most dramatic manifestation was the Seattle Coalition, which in late 1999, brought together 30,000 demonstrators organized by labor groups with 20,000 from environmental movements in protest against World Trade Organization policies (Hawken, 2000). Since the 1980s, accelerating since the mid-1990s, unions have moved beyond traditional bases, in some cases, to build enduring alliances with human rights, environmental, religious, student, feminist and other community groups. From our case studies, two variables stand out: support from one or more national unions, and the spread and mobilization of activist networks at local level. Activist networks are typically led by 'bridge builders' with interests, contacts and backgrounds that extend beyond the labor movement (Brecher and Costello, 1990; Rose, 2000). The framing of campaigns around broad issues along with 'institutionalization' (progress beyond ad hoc one-issue alliances to a deepening of ties) also appear critical for success and staying power.

Robert Kuttner has described the living wage movement as 'the most interesting (and under-reported) grass roots enterprise to emerge since the civil rights movement' (Pollin and Luce, 1998: 1). In cities across the country, coalitions of activists campaign for a local minimum wage considerably higher than the national minimum, with notable cases of success. Examples include the Community Labor Alliance in Connecticut (with living wage laws passed in New Haven in 1997 and Hartford in 1999), the Santa Clara County Central Labor Council in alliance with Working Partnerships USA and 60 other groups (pushing the San Jose City Council to adopt living wage policies in 1998), and the Los Angeles Living Wage Coalition (with broad popular support resulting in victory in early 2000 ). In all cases, successful coalitions were led by local unions with active national support, with networks of overlapping activists in long-term relationships with a variety of community groups, churches and other organizations.

The anti-sweatshop movement since the late 1990 s offers another example of successful coalition building, with UNITE the key union involved. The Union Summer project, launched by the new Sweeney-led AFL-CIO in 1996, placed hundreds of college students in summer internships in organizing and collective bargaining campaigns, encouraging them to build centers of labor activism on their return to campus. The Students Against Sweatshops movement quickly took hold on American campuses, with successful sit-ins at many universities and the formation of a national umbrella organization, United Students Against Sweatshops (USAS). While UNITE and Union Summer helped to launch the movement and UNITE has underwritten the costs of USAS national meetings, campus-based coalitions are autonomous. Critical components include national union support (especially at the beginning, for resources and education); forming permanent local organizations; and the capacity to mobilize thousands of students for demonstrations, sit-ins and other activities.

Sustainability alliances typically have labor and environmental groups at their core (Moberg, 1999; Rose, 2000). Today, there are scores of such coalitions working together on a 
wide variety of issues, from living wage and anti-sweatshop campaigns to toxic waste sites, workplace health and safety, clean air and global warming. While local coalitions predominate, they typically receive important support from national labor and environmental organizations, including a national umbrella grouping called the Alliance for Sustainable Jobs and the Environment. The Alliance was formed in the losing fight against the North American Free Trade Agreement (NAFTA) in 1993, regrouped to defeat fast-track legislation in 1997 (Shoch, 2001), and provided the framework for the Seattle demonstrations (Hawken, 2000). Active members at national level range from steelworkers and carpenters to Friends of the Earth and the Sierra Club. While tensions over global warming policies, oil-drilling in Alaska, and vehicle economy requirements have made collaboration problematic, more than 200 member groups remain committed to fighting anti-labor and anti-environmental legislation at national and local levels, including local coalition efforts in dozens of cities and regions.

In spite of these promising examples, the reality is that most unions continue to think about coalitions in narrow terms. Since the 1980s, for example, unions have increasingly relied on corporate campaigns as a source of leverage during contract negotiations and organizing drives, including outreach to potential allies to apply pressure on the employer. If coalitions emerge they tend to be on union terms, and typically dissolve when the campaign ends. However, there are examples of union-initiated coalitions that demonstrate long-term potential. The SEIU's Justice for Janitors campaign, for example, is a national effort to reorganize the building services industry in major cities after a period of deunionization. Faced with a loss of members as building owners eliminated jobs and turned to janitorial service contractors, the SEIU created a combined organizing and bargaining strategy based on the corporate campaign model, with special attention to building coalitions in communities. Perhaps the best example is Los Angeles, where thousands of janitors have been organized and won major improvements in a series of campaigns beginning in the early 1990s, each one building a broader and deeper level of community support (Erickson et al., 2001; Milkman and Wong, 2001).

Building alliances with groups such as environmentalists can be difficult, which is why support from national unions is so important. Equally important in making coalitions vibrant and enduring on the local level are the mobilization efforts of bridge-building activists, from inside the labor movement and beyond. Lastly, the development of ongoing relationships and common experience is essential to deepen the trust among actors and organizations, laying the groundwork for expanded collaboration around common interests.

\section{Labor-Management Partnership}

There seem to be two broad types of labor-management partnership. The first is a model prevalent since the 1980 s, driven by the intensification of market competition and union decline. Key characteristics include commitment to a new spirit of labor-management cooperation, joint committees on various themes, concession bargaining, mutual problem solving and cost-cutting. The second, more recent model, with partnerships developing often in the aftermath of a strike or organizing drive, transcends established adversarial relations and promotes a tradeoff in which the union agrees to support the company in return for company acceptance of the union.

Partnership agreements between Levi-Strauss and UNITE and between Kaiser Permanente and a consortium of its unions are examples where unions promote the company, provide input into 
management decision-making and negotiate peak as well as plant-level settlements, while the employer to some extent incorporates the union and agrees not to oppose organizing efforts in unrepresented units and facilities. Two recent cases where passionate, well-organized strikes were followed by extensive partnership agreements, at least on paper, are Boeing with its Engineers' union and Verizon with the CWA and IBEW.

While the first model has produced positive results (at Ford, GM, Xerox, Bethelem Steel, and Alcoa) and has stabilized troubled plants and firms, cooperation often remains superficial, with little active employee participation and real partnership extended only to a core of company and union officials. The second model also may be problematic (here too, renewed conflict may ensue) but nonetheless, offers more substantial potential gains in participation and representation.

Where both types have succeeded, there is typically national union support and some degree of expanded participation. However, the first model is often limited to regularized cooperative relationships among key managers and union officials or appointees. The second model, by contrast, promotes the mobilization of union activists in organizing campaigns at nonunion workplaces. The first often stagnates in the absence of meaningful participation, while the second fails (from a union viewpoint) without mobilization for rank-and-file organizing. The development of trust through ongoing relationships is difficult, yet essential to the success of either.

As yet, it does not appear that the spread of partnerships of either variety has contributed substantially to labor movement revitalization in the USA. Specific partnership agreements can and have yielded positive effects, for particular firms, unions and workers (Osterman, 1994). For many activists, such agreements belong to the failed approaches of the 1980s; yet the partnership model could play a role in union organizing strategy and in the long-term vision that unions develop for the workplace. The SEIU, for example, now has a 'high road' approach for organizing hospitals and other workplaces, embracing a strategy that emphasizes the positive and attempts to lay the groundwork for future labor-management partnerships. For professional, technical and other white-collar employees, such an approach may work better than the traditional adversarial model. Since the SEIU has also been a strong advocate for social movement unionism, this raises the intriguing question of the extent to which rank- and-file mobilization can lay the groundwork for expanded relations of partnership.

Enhanced relations of labor-management partnership may well prove complementary to today's sometimes militant organizing efforts. Ironically, the success of each may ultimately rest upon the success of the other. Cases such as Verizon, Kaiser Permanente and Boeing (all with extensive partnership agreements, but troubles in implementation) offer tests of the extent to which labor-management partnership, rank-and-file mobilization and future organizing or bargaining success are compatible. In addition to obviously important company strategies, our evidence indicates a greater likelihood of success where national unions are supportive, rank-andfile participation is extensive and labor-management partnership is regularized and deepened over time.

\section{Organizational Change}

The labor movement's quest for revitalization has involved restructuring at federation and 
national union levels. Since 1995 the AFL-CIO has completed internal reorganization of staff departments and made substantial progress in redesigning field operations. Efforts to redefine the federation's relationship with affiliates have been partially successful, although resistance from the latter has limited progress on this front. Some national unions have engineered their own internal restructuring, largely aimed at elevating the importance of organizing. In addition, several unions have pursued mergers.

The AFL-ClO's staff reorganization was completed in 1996 and included the creation of several new departments, the merger of a number of units and expansion of certain activities. The most important new departments are Organizing (which includes the Organizing Institute), Corporate Affairs, and Public Affairs. The Organizing Department has been charged with establishing organizing as a priority and assisting affiliates with strategy and staffing concerns. The Corporate Affairs Department has concentrated on capital strategies, workplace democracy and strategic research. The Department of Public Affairs has contributed an extensive, greatly improved communications and public relations effort.

Other than new departments, the most important change in the AFLCIO's internal structure has been expansion and reorganization of the field operation. The old Department of Organization and Field Services was renamed the Field Mobilization Department. Field staff are now expected to promote activism, a reversal of the former role of passive observers. The most important vehicle for building activism is the ongoing campaign to breathe life into central labor councils (CLCs), which formerly functioned largely as clubs for local union officials. With Field Mobilization's union cities programme, $\mathrm{CLCs}$ are now encouraged to engage union members in 'street heat' events, to promote grass-roots organizing and political activism, and facilitate mutual support among affiliated local unions (Eimer, 1999; Kriesky, 2001). This effort is being extended by merging small CLCs in an innovative 'new alliance' reorganization process, under the combined sponsorship of Field Mobilization and the state federation. The goal is to create a system of central area bodies large enough to employ full-time staff to work with local activists.

This internal reorganization is best viewed as part of an effort to redefine the relationship with affiliated national unions and to strengthen the role of the center. Perhaps the most intriguing aspect of the initiative is the work of Field Mobilization, reaching directly into local unions through a network of newly energized CLCs. Also successful has been the increased prominence of AFL-CIO political operations (described earlier), built upon a longstanding consensus that the federation should coordinate electoral and legislative efforts.

With outspoken support from the Sweeney leadership, the Organizing Department has promoted organizing as a priority, but has not been able to offer the technical assistance unions need as they struggle with the challenges of radical change. Avoiding issues such as strategic planning, organizational assessment and restructuring, the Organizing Department has missed an opportunity to make a deeper impact. With substantive support lacking, many affiliates have done little beyond rhetoric to embrace the message and have continued to pursue their own agendas. A case in point is organizing jurisdiction. As recently as 1999 a proposal was considered to offer explicit jurisdictional preference to unions engaged in industry-wide and joint organizing efforts. Consensus, however, has been elusive: some affiliates pursue industrial unionism, others promote occupational unionism, and most are unwilling to forgo promising opportunities even outside the union's self-described jurisdiction.

Ultimately, the AFL-CIO has backed off, revising its organizing objectives to fit the reality. 
The change in tone in the 1998 and $2001 \mathrm{AFL}-\mathrm{ClO}$ programme summaries reflects this more accommodating role: the former spoke of 'leading5 the change to organize and 'sponsoring strategic organizing campaigns', but the latter merely emphasizes 'helping affiliate unions' and 'providing strategic research and other assistance'. As with bargaining, national unions have retained authority.

Internal restructuring has been modest inside most national unions. With change typically top-down, there is precious little evidence of initiatives to increase member involvement beyond limited participation in organizing. The potential and limits of internal restructuring are reflected in two notable cases: the SEIU and the United Brotherhood of Carpenters (UBC). The former now allocates half its national budget to organizing and expects locals to follow suit. To move the process along, the union has engineered mergers of small locals. Broad support among elected leaders for the organizing priority has helped, as have a few carefully orchestrated trusteeships (including New York City and Boston). Removal of old- line, heavy-handed local leaders has been applauded in the media and the broader labor movement, and has simultaneously allowed SEIU President Andy Stern to appoint as trustees progressive unionists committed to organizing. Topdown structural change has been matched by aggressive grass-roots organizing, allowing the SEIU to continue its steady growth while other unions struggle.

UBC's top-down restructuring has stirred more controversy internally and externally. Shortly after assuming the presidency in 1995, Doug McCarron cut national office staff by half, eliminated departments and rented out a substantial part of the union headquarters to generate revenues. These changes helped fund a shift of half the union's resources into organizing. Subsequently, McCarron reorganized the union's regional and local structure, eliminating many locals and shifting control of resources to regional councils dominated by his political allies. These changes have allowed the UBC to expand its organizing programme. In March 2001, the UBC seceded from the AFL-ClO, ostensibly because the Sweeney administration had compromised its commitment to organizing. It is widely assumed elsewhere in the labor movement that the move was actually taken to give the UBC more freedom in raiding other building trades unions (Orrfelt, 2000). Although the steps taken by the UBC are extreme, they are consistent with the troubling tendency of many US unions to approach organizing from a narrow perspective tied to institutional preservation.

Since Sweeney became president the number of AFL-ClO affiliates has dropped from 75 to 64 , and with the exception of the UBC defection, the decline is the result of mergers. Many have involved a smaller union going through difficult times being absorbed by a larger union with deeper pockets: for example, in 1996, the 40,000-member Aluminum, Brick and Glass Workers merged with the United Steelworkers, and in 1997, the 19,000-member International Woodworkers joined the Machinists. Others have been pursued by larger unions looking to extend their presence in an occupation or industry, such as the SEIU mergers with the Committee of Interns and Residents in 1997 and the National Health and Human Service Employees Union (1199) in 1998. Still others are presented as mergers of two organizations with individual identities that will be preserved in the structure of the new, stronger unified force. The best example of the latter is the 1999 merger of the United Paperworkers with the Oil, Chemical and Atomic Workers to form PACE, the Paper, Atomic and Chemical Employees.

Although mergers do improve the ability of troubled unions to weather hard times, they are typically followed by long transition periods and limited integration. It is often not clear that 
the merged organization has any more economic and political power than the sum of the two previously separate unions (Chaison, 2001); and often the merger route has detracted from real union growth by providing an easy way to grow without expending resources on organizing.

This conclusion is consistent with our overall argument. Top-down approaches are of limited value by themselves because institutional preservation takes priority over movement building. When combined with efforts to mobilize members, results are more rewarding. In this context, it is not surprising that AFLCIO efforts to restructure have been most successful in field operations, where the union cities and new alliance programmes are helping to revitalize labor at the grass roots by combining activism with structural reform. This is not to say that other changes at the AFL-CIO and within national unions are unimportant, but rather to re- emphasize our belief that structural reforms alone are insufficient to assure revitalization.

\section{International Solidarity}

Because unions remain nationally based, most transnational union activities arise as interorganizational cooperation through voluntary participation in cross-national networks through which unions give and receive material assistance, coordinate political and bargaining agendas and resolve jurisdictional conflicts. They exchange information on employers, working conditions, and industry regulations, and seek pressure points to be used in transnational corporate campaigns. The goals of participation in transnational labor networks include: giving and receiving direct support in collective bargaining and organizing; giving and receiving information; and coordinating national political agendas, in particular, to influence transnational politics on the global stage.

There are two important types of tactics used by US unions relating directly to transnational collective bargaining: corporate campaigns and secondary industrial action. Many unions have developed transnational capabilities for corporate campaigns in support of organizing drives and collective bargaining. Such campaigns begin with analysis of the structure of the targeted corporation for weaknesses and pressure points. Because corporate structures are increasingly transnational, corporate campaign strategy often leads to alliances with unions and political actors in other countries, in order to access crucial pressure points. Experts from the International Trade Secretariats (now called Global Union Federations) serve as 'international campaign consultants', assisting affiliates in making contacts and launching their campaigns. Such campaigns are pursued most vigorously in industries with transnational capital structures, especially where employers are aggressively anti-union. HERE, for example, targets international hotel chains with corporate campaigns in support of organizing drives. While individual hotels may be bound to particular locations and markets, these hotels are increasingly owned by multinational conglomerates. HERE's transnational activities arise as an extension of organizing strategy, in response to the changing structure of capital.

American unions sometimes use traditional industrial action in support of unions in other countries, despite draconian legal restrictions on secondary boycotts. The International Association of Machinists (IAM), for example, refused to service British Airways aircraft during a 1997 strike by BA flight attendants. The International Longshore and Warehouse Union (ILWU), the dockers' union on the west coast, has conducted two major secondary industrial actions in support of locked-out dock workers in recent times, those in Liverpool in 1997 and in Australia in 
1998. In each case, ILWU dockers, at significant legal risk to themselves, refused to unload cargo that had been handled by replacement workers. Both IAM and the ILWU actions had strong support from the union leadership, although in the case of the ILWU, the boycotts were organized by transnational rank-and-file networks. Both actions reflected broader global institutionalized cooperation involving the International Transportworkers' Federation (ITF). The IAM action came at the request of the ITF, which had declared the BA strike a 'strategic priority'. In the Liverpool strike, the ITF (which would have been liable to legal sanctions in Britain) was not officially involved, but Liverpool dockers used ITF contacts to manage a global campaign (Lavalette and Kennedy, 1996). International solidarity action in the 1998 Australian dispute was part of a global strategy sanctioned and facilitated by the ITF.

While transnational campaigns are the most visible manifestations of international labor activity, they occur infrequently and depend on preexisting networks; as Ramsey (1997) has pointed out, by the time there is a crisis and solidarity is needed, it is too late to begin building relationships. There appears to be a correlation between informational networks and solidarity actions: ILWU activists, for example, through a variety of personal and institutional connections, discuss with foreign counterparts their experiences with safety regulations, port regulation and repertoires of industrial action. These same contacts come into play as a basis for organizing transnational industrial action.

The Battle of Seattle in 1999 (discussed earlier) can also be viewed as a symbol of international union strategy: in this high-profile campaign, American unions showed a strong capacity to mobilize members and to build broad coalitions addressing the very nature of the new global economy. If the US experience is typical, labor transnationalism involves national unions acting across borders utilizing transnational networks. Once again, both active national union support and networks of activists are critical. Nonetheless, steps toward international solidarity have been tentative and disjointed, with no clear strategic consensus to guide future initiatives in this arena.

\section{Conclusion}

Whether the revitalization efforts of the US labor movement succeed or fail may ultimately be determined by whether the various innovations we have described can be melded into a coherent and comprehensive strategy for transformation. To do so, unions must learn to work together to reposition labor as an essential core of a new social movement (Turner and Hurd, 2001). Some elements are already in place, even in the absence of a clear vision for a reconstructed labor movement. There is a new emphasis on organizing and a recognition that success requires both strong national backing and effective grass-roots activism. Political success is tied to a rejuvenated coordinating role for the AFL-CIO plus a strong emphasis on membership mobilization in the field, with no clear pay-off yet in the regulatory environment for unions. Coalition building has been sporadic, with important breakthroughs in recent years. Although the benefits of labor-management partnerships are tenuous, experience demonstrates that where unions have sufficient power and vision, it is possible to engage members while stabilizing bargaining relationships and gaining access to non-union facilities.

Organizational change is essential for union revitalization and must involve both a strengthened center and a movement open to mass participation. Perhaps the least progress has 
been made in building international solidarity, but even here there have been encouraging signs.

Sources of union revitalization in the American case are therefore varied. Two threads in particular pass through all of our cases, providing together a useful preliminary explanation for innovation and its relative success. The first is national union support for strategic innovations at the local level; the second is a readiness for rank-and-file mobilization with activist local leadership. In addition, the consolidation and deepening of relationships over time (especially in network and coalition building) appear critical for lasting reform efforts and strategic union success.

If institutions, mobilization, and coalition networks are important, and our research persuades us they are, then we need to move beyond existing literatures that privilege one or the other. Effective policy innovations are not driven mainly from the top-down, bottom-up or outside, but require intensive interactions among all three, together reinforcing and driving strategic change.

\section{Acknowledgement}

The authors have benefited from the input of colleagues Kent Wong of UCLA and Bill Fletcher of the TransAfrica Forum. Thanks are also extended to Nathan Lillie, Richard Belfield, lan Greer, Sarah Swider and Karen Pocious for research assistance; Brigid Beachler and Robin Burke for technical support; the Ford Foundation and Cornell University for generous research funding; and the ILO and Friedrich-Ebert-Stiftung for conference funding and support.

\section{References}

Bernstein, A. (2000) 'Labor's Labors Aren't Lost', Business Week, November: 27.

Brecher, J. and Costello, T (1990) Building Bridges: The Emerging Grassroots Coalition of Labor and Community. New York: Monthly Review.

Brecher, J. and Costello, T. (1994) Global Village or Global Pillage: Economic Reconstruction from the Bottom Up. Boston: South End Press.

Bronfenbrenner, K. (1997) cThe Role of Union Strategies in NLRB Certification Elections', Industrial and Labor Relations Review 50: 195-212. 
Chaison, G.N. (2001) 'Union Mergers and Union Revival: Are We Asking Too Much or Too Little', in L. Turner, H. Katz and R. Hurd (eds) Rekindling the Movement: Labor's Quest for 21st Century Relevance, pp. 228-55. Ithaca: ILR Press.

Dreyfus, R. (2000) 'Rousing the Democratic Base', The American Prospect, November, 6.

Durkin, T. (2001) Took Who's Playing Footsie With the Teamsters', The National Journal, 28 July.

Eimer, S. (1999) 'From "Business Unionism" to "Social Movement Unionism": The Case of the AFL-CIO Milwaukee County Labor Council', Labor Studies Journal 24(2).

Erickson, C , Fisk, C, Milkman, R., Mitchell, D.J.B. and Wong, K. (2001) 'Justice for Janitors in Los Angeles: Lessons from Three Rounds of Negotiations'. Paper presented at the Collective Bargaining Workshop, Cornell University, 2 March.

Fletcher, B. Jr. and Hurd, R. (2001) 'Overcoming Obstacles to Transformation: Challenges on the Way to a New Unionism', in L. Turner, H. Katz and R. Hurd (eds) Rekindling the Movement: Labor's Quest for 21st Century Relevance, pp. 182-208. Ithaca: ILR Press.

Foerster, A. (2001) 'Confronting the Dilemmas of Organizing: Obstacles and Innovations at the AFL-ClO Organizing Institute', in L. Turner, H. Katz, and R. Hurd (eds) Rekindling the Movement: Labor's Quest for 21st Century Relevance, pp. 155-81. Ithaca: ILR Press.

Hawken, P. (2000) 'On the Streets of Seattle', The Amicus Journal, spring: 29-51.

Hoffman, K.B. (2000) 'Unions, Blacks Helped Democrats Gain Tie in Senate', Bergen County Record, 3 December.

Kelly, J. (1998) Rethinking Industrial Relations: Mobilization, Collectivism and Long Waves. London: Routledge.

Kriesky, J. (2001) 'Structural Change in the AFL-CIO: A Regional Study of Union Cities' Impact', in L. Turner, H. Katz, and R. Hurd (eds) Rekindling the Movement: Labor's Quest for 21st Century Relevance, pp. 129-54. Ithaca: ILR Press.

Lavalette, M. and Kennedy, J. (1996) Solidarity on the Waterfront: The Liverpool Lock Out of 1995/1996. Merseyside: Liver Press.

Milkman, R. and Wong, K. (2001) 'Organizing Immigrant Workers: Case Studies from Southern California', in L. Turner, H. Katz and R. Hurd (eds) Rekindling the Movement: Labor's Quest for 21st Century Relevance, pp. 99-128. Ithaca: ILR Press. 
Moberg, D. (1999) 'Greens and Labor: Two Powerful Movements Gang Up on Polluters', Sierra, January/February: 46-54.

Molyneux, G. (1996) 'The Big Loser in Elections? It's Not Labor', Los Angeles Times, 17 November.

Orrfelt, M. (2000) 'Reformers Join Carpenters Convention', Union Democracy Review, October/November.

Osterman, P. (1994) 'How Common is Workplace Transformation and Who Adopts It?', ILR Review 47(2): 173-88.

Pollin, R. and Luce, S. (1998) The Living Wage: Building a Fair Economy. New York: New Press. Ramsey, H. (1997) 'Solidarity at Last? International Trade Unionism Approaching the Millennium', Economic and Industrial Democracy 18: 503-37.

Rose, F. (2000) Coalitions Across the Class Divide: Lessons from the Labor, Peace and Environmental Movements. Ithaca: Cornell University Press.

Shoch, J. (2001) 'Organized Labor versus Globalization: NAFTA, Fast Track and PNTR with China', in L. Turner, H. Katz and R. Hurd (eds) Rekindling the Movement: Labor's Quest for 21st Century Relevance, pp. 275-313. Ithaca: ILR Press.

Soskice, D. (2000) 'Macroeconomic Analysis and the Political Economy of Unemployment', in T. Iversen, J. Pontusson and D. Soskice (eds) Unions, Employers, and Central Banks:

Macroeconomic Coordination and Institutional Change in Social Market Economies, pp. 38-76. Cambridge: Cambridge University Press.

Sweeney, J.J. (1996) America Needs a Raise: Fighting for Economic Security and Social Justice. Boston: Houghton Mifflin.

Turner, L. and Hurd, R. (2001) 'Building Social Movement Unionism: The Transformation of the American Labor Movement', in L. Turner, H. Katz and R. Hurd (eds) Rekindling the Movement: Labor's Quest for 21st Century Relevance, pp. 9-26. Ithaca: ILR Press.

Voss, K. and Sherman, R. (2000) 'Breaking the Iron Law of Oligarchy: Union Revitalization in the American Labor Movement', American Journal of Sociology 106(2): 303-49.

Wallerstein, M. and Golden, M. (2000) 'Postwar Wage Setting in the Nordic Countries', in T Iversen, J. Pontusson and D. Soskice (eds) Unions, Employers, and Central Banks: Macroeconomic Coordination and Institutional Change in Socia/ Market Economies, pp. 107-37. Cambridge: Cambridge University Press. 